\title{
Large Shareholder's Identity and Stock Price Synchronicity: Evidence from a MENA Market
}

\author{
Adel Bino ${ }^{1}$, Diana Abu-Ghunmi ${ }^{1}$, Mohammad Tayeh ${ }^{1} \&$ Dua'a Shubita $^{1}$ \\ ${ }^{1}$ Department of Finance, School of Business, The University of Jordan, Amman, Jordan \\ Correspondence: Mohammad Tayeh, Department of Finance, School of Business, The University of Jordan, Amman \\ 11942, Jordan. Tel: 962-6-535-5000 ext. 24271.
}

Received: November 27, 2015

Accepted: December 16, $2015 \quad$ Online Published: January 11, 2016

doi:10.5430/ijfr.v7n1p135

URL: http://dx.doi.org/10.5430/ijfr.v7n1p135

\begin{abstract}
This paper investigates the association between large shareholder's identity and stock price synchronicity in a country where investor protection is weak. Results show that stock prices in Jordan have synchronous behavior especially when the firm is large, consistent with previous empirical evidence on stock price behavior in low per capita GDP countries. Most of the public corporations are owned and controlled by families. In most of the family-controlled firms, the controlling family is also involved in firm's management leading to loose separation between ownership and management. Furthermore, stock prices of family (government)-controlled firms are significantly less (more) synchronous than those of widely held corporations. The pyramid structure is the most widely used indirect control mechanism but results in little deviations between ownership and control.
\end{abstract}

Keywords: synchronicity, ownership structure, cash flow rights, voting rights

\section{Introduction}

Concentrated ownership structure by which large shareholders control the firm remains the dominant feature of corporations in both developed and developing countries (see for example, La Porta et al. 1998; LaPorta et al. 1999; Claessens et al. 2000). However, significantly larger concentration of ownership in the hands of blockholders is particularly observed in countries where legal protection of investor rights is weak (La Porta et al. 2002) (Note 1). The quality of investor rights protection from corporate insiders, in turn, has been found negatively related to the extent by which stock prices exhibit synchronous behavior (Morck et al. 2000). In this paper, we investigate the association between ownership structure and stock price synchronicity on the firm-level in a country characterized by weak protection of investor rights (Note 2). Unlike previous research, this enables us to directly investigate controlling shareholder's role with less concern about the confounding effects of the quality of commercial laws. More specifically, we seek to examine how the identity and incentives of large (controlling) shareholders relate to stock price synchronicity in the absence of legal measures that can provide subsidized monitoring of corporate insiders.

In a poor legal protection environment, the absence of legal deterrence enables large shareholders to easily expropriate minority shareholders' rights by taking actions that maximize their own private benefits rather than firm value. Thus, large shareholders can choose not only their actions but also the type and time of information they disclose about the firm (Jin and Myers, 2006; Jiang et al., 2013). The link between firm-specific information and stock price behavior can be traced back to Roll (1988) who finds that only $20 \%$ of daily stock price changes in NYSE can be explained by market-wide and industry-specific factors. Morck et al. (2000) and Campbell et al. (2001) do similar analyses using more recent data and find that as the U.S market developed, the percentage of stock price changes explained by changes in market conditions (i.e., $R^{2}$ ) has dropped significantly over time. This negative correlation between capital market development and firms' average $R^{2}$ is not confined to the U.S market but rather exists in cross-country data as well. Morck et al. (2000) build on the observation that stock prices in low per capita gross domestic product (GDP) countries move in more synchronous manner, as evidenced by their higher average $R^{2} \mathrm{~s}$, than in high per capita GDP countries and show that such differences can be explained by differences in the extent to which a country's laws protect investor rights. Countries with poor protection of investor rights are expected and found to have more concentrated ownership structures (Giannetti and Koskinen, 2010). La Porta et el. 1999). 
The way firms are owned and controlled whether directly by owning enough cash flow rights to gain majority voting rights and/or indirectly using shares with superior voting rights (shares with more than one voting right), the pyramid structure, and/or cross-holdings has been investigated in different regions and countries. The evidence is that even in wealthy economies firms are mainly controlled by families or the state unless the country has very good investor protection laws (La Porta et al. 1999). Family control is far more pronounced in East Asian corporations where the pyramid structure and cross-holdings are frequently used by investors to gain control over firms (Claessens et al., 2000). The use of pyramids is more extensive in majority of Russian corporations which are controlled either by state or by anonymous private owners through not only the use of pyramids but also golden shares (a feature that grants large control rights without cash flow rights) (Chernykh, 2008). This is in contrast to corporations in the Western European countries where most of the financial and large corporations are widely held while non financial and small corporations are mainly controlled by families and the use of pyramids and cross holdings to control firms is only marginal (Faccio and Lang, 2002). As for the Middle East and North African (hence, MENA) region, the region remains largely unexplored in terms of how firms are owned and controlled although its contribution to world economy has been increasing and its countries have been attracting significant foreign direct investment (Note 3). Along these lines, we provide answers from a country (namely, Jordan) that is representative of the MENA region. We use data from the Jordanian market because it is the least volatile among the MENA countries (Lagoarde-Segot, 2009). Countries of the MENA region differ drastically from developed countries and other emerging markets in many respects including how principal-agent relationships and financial markets are structured and, more importantly, how social norms shaped corporate structure and institutional environment. Studying the stock behavior and corporate governance structure in Jordan will contribute to understanding the workings of corporate governance mechanism and stock price behavior in other MENA countries as well, as these countries have similar regulatory systems and investment environment.

We are not the first to investigate the association between large shareholder's identity and stock price synchronicity. For example, An and Zhang (2013) find that stock price synchronicity is negatively related to ownership by dedicated institutional investors and Gul et al. (2010) find that synchronicity is higher when the largest shareholder is government and that foreign ownership is inversely related to synchronicity. However, previous evidence comes either from a developed country or a country with strong investor protection laws. We contribute to this research in two ways: First, we present evidence from a country with extremely weak investor protection laws and therefore, we are able to directly test for the role of the largest shareholder as commercial laws provide no significant investor protection. Second, we provide evidence from an emerging market as little research exists on the role of large shareholders in general and on the role of families and the government, in particular, in emerging markets (Claessens and Yurtoglu, 2012). This evidence is relevant because there are huge variations in the firm-level governance among emerging markets compared to developed markets (Klapper and Love, 2004).

We find that stock prices in Jordan do have synchronous behavior consistent with Morck et al. (2000) findings for low per capita GDP countries. Furthermore, large firms' stock prices are more synchronous than those of small firms while family controlled firms' stock prices are less synchronous than those of widely held firms. Our results are also consistent with La Porta et al. (1998) results that ownership structures of firms in French origin civil-law countries exhibit significant concentration. Like most of the MENA countries, Jordan is a civil law country and most of the Jordanian publicly traded firms are owned and controlled by families directly and/or indirectly using a pyramid structure and/or cross-holdings resulting in varying deviations between ownership and control. In addition, the controlling family is heavily involved in firm's management, thus, aligning ownership and management. The use of indirect control mechanisms in Jordan is not due to certain limits imposed on ownership stakes by commercial laws because Jordanian commercial laws place "not so restrictive" limits on ownerships by individuals and corporations, besides, those laws do not seem to be properly enforced. In other words, pyramid structures and cross-holdings are not the result of shareholders attempts to maneuver around restrictive ownership regulations.

The paper proceeds as follows: in the next section we give an overview of ownership regulations in Jordan and discuss the relevant literature and develop our hypotheses, in Section 3 we describe the data construction and methodology, section 4 presents the empirical results, and section 5 concludes the paper.

\section{Literature Review}

\subsection{Institutional Environment and Corporate Ownership Regulations in Jordan}

Jordan's equity market is different from those of both developed and other emerging Markets. Compared to developed markets, the information environment in Jordan in which financial securities are traded is not yet mature enough to allow for perfect and timely verification of either market-wide or firm-specific information which leads to 
noise trading. One reason behind the dominance of noise trading over informed trading is the weakness of relevant commercial laws and the ineffectiveness of the system designed to enforce them (Note 4). Another issue is the lack of well-structured trading mechanism that would limit excessive volatility and promote stock liquidity which enables traders to manipulate prices and trading volume (Note 5). The adverse consequences of such problems are exacerbated by the absence of active institutional shareholders and informed arbitrageurs. Compared to other emerging markets, on the other hand, Lagoarde-Segot (2009) finds that while emerging markets are generally inefficient, the Jordanian equity market is one of those emerging markets that are moving rapidly towards information efficiency with the lowest market volatility. Thus, the Jordanian market offers an ideal setting for testing the association between corporate governance measured by ownership structure and stock price behavior because: First, it is less likely that market volatility and stock price synchronicity may be driven by political risk, Second, equity prices are becoming closer to being fair reflections of true firm value, and Third, it enables us to focus on the role of large shareholders as corporate monitoring can solely come from within the firm.

Jordan's stock market, the Amman Stock Exchange (hence, ASE), was established in 1978 making it the second oldest stock market in the MENA region after the Egyptian Stock Exchange. Similar to all other MENA countries, the commercial laws of Jordan originate from the French-civil law. Most importantly, commercial laws in Jordan require that ordinary shares carry one vote per share (i.e. shares with superior voting are not allowed) and impose less stringent restrictions on shareholdings by firms and individuals. Stock ownerships of public corporations by firms and individuals are regulated through the Central Bank of Jordan, Jordan Securities Exchange Commission, and the commercial law of the government. The banking law No. 28 for year 2000 prohibits banks from owning more than $10 \%$ of the shares of another bank or company but exempts from this prohibition banks' ownerships that were acquired prior to year 2000 provided that those ownerships do not exceed $50 \%$ unless they are approved by the central bank. Item No. 45 of the Jordan Securities Commission law for year 2002 prohibits individuals and firms from owning more than $40 \%$ of the shares issued by any financial or non financial firm unless they were acquired through an "ownership offer" approved by the securities commission. Finally, Jordanian commercial laws prohibit foreign investors from owning more than $50 \%$ of the capital of firms that operate in certain types of the transportation industry, owning more than $49 \%$ of firms that operate in air transportation and aircraft rental industries, and owning any shares in firms operating in particular transportation, security, and sports industries. In addition to these laws, the Central Bank of Jordan and the Securities Exchange Commission have recently issued corporate governance guidelines (not mandatory to be applied by firms) that set rules that aim at creating a proper corporate governance environment in both financial and non financial corporations by, for example, requiring that the CEO and the chairman of the board of directors be two unrelated persons.

Thus, Jordanian investors and non bank corporations are allowed to have no more than $40 \%$ ownership stake in public firms and possibly own more than that provided that the transaction is approved by the Jordanian Securities Commission, banks can have no more than $10 \%$ ownership stake in another bank or corporation and possibly own more than that if the transaction is approved by the Central Bank of Jordan, and foreign firms and individuals can have unlimited ownership stake in any Jordanian firm except in firms that operate in certain types of the transportation, security and sports industries where they can have no more than $50 \%$ or $49 \%$ ownership stake depending on the type of the industry. All the laws that regulate ownership stakes in Jordan place restrictions only on direct ownerships and therefore, firms' and individuals' ownership stakes can legally exceed their limits using indirect mechanisms (i.e., pyramid structure and/or cross-holdings).

\subsection{Related Literature and Hypotheses Development}

The questions addressed in this paper pertain to two main strands of literature. First, is the research that examines the quality of public investor rights protection from legal perspective (measured by character of legal rules and quality of law enforcement) and from financial point of view (measured by ownership concentration and deviations between cash flow and control rights). This line of research is pioneered by La Porta, Lopez-De-Silanes, Shleifer, and Vishny who show that countries that use the French origin civil law have weaker investor protection rules than those of countries that use English origin common law, and have less developed capital markets (La Porta et al. 1997). La Porta et al. (1998) show that under the French-civil-law, investors are not only poorly protected but also the system that enforces the laws is weak. The legal approach of protecting outside investors is essential because leaving markets without a governance system imposed by law does not encourage them to set up a corporate governance mechanism that protects investors (La Porta et al. 2000). Nevertheless, when the quality of public investor protection provided by laws is poor and the enforcement of such laws is weak, shareholders may seek such protection through controlling the firm (Giannetti and Koskinen, 2010). Investors can hold ownership stake that is large enough to enable them to control the firm (i.e., concentrated ownership) so that they can effectively monitor managers to 
reduce the risk of being expropriated by them. Consistent with this argument, ownership concentration is found to be higher in French-civil-law countries where investors are poorly protected than in common-law-counties (La Porta et al. 1998, and Boubakri et al. 2005). Later, Burkart et al. (2003), present theoretical evidence supporting this negative relationship between the quality of investor protection and ownership concentration. Since commercial laws in Jordan originated from the French Civil law, we hypothesize,

\section{H1: Ownership of corporations in Jordan is concentrated in the hands of large individual (few) shareholder(s).}

Owning large cash flow rights in the firm is not the only way by which shareholders can control the firm. Shareholders can resort to cross-shareholdings (where firms hold ownership stakes in each other) and/or forming pyramids of ownership (where some public firm (s) is owned and controlled through some other public firm (s)). The use of such indirect control mechanisms results in varying degrees of separation between ownership and control (i.e., deviation of cash flow rights from voting rights) (Almeida and Wolfenzon, 2006). The controlling shareholders can exercise their control by intervening in firm's management through appointing the CEO and/or choosing members of the board of directors who are somehow related to the controlling shareholders, thus, resulting in aligning ownership and management. In this regard, firms can be compared along these two dimensions: first, whether the firm's ownership structure exhibits deviations between ownership and control and, second, whether firm's ownership and management are separated from each other. Ownership structures where control and ownership are separated and control and management are aligned allow controlling shareholders to expropriate minority shareholders, thus, making minority shareholders even less protected when laws do not provide enough public investor protection. Hence, we hypothesize that,

H2: In a country where minority shareholders' rights are poorly protected, indirect control mechanisms are frequently used to gain control over firms.

The second line of literature to which the questions of this paper are related is the research that investigates stock price behavior both theoretically and empirically. The well known Capital Asset Pricing Model (CAPM) and the Arbitrage Pricing Theory (APT) predict that stock price behavior or return covariance can be explained by its sensitivity to common factor(s) and firm-specific factors. Roll (1988) finds that, on average, $35 \%$ of monthly and $20 \%$ of daily stock price changes in NYSE can be explained by changes in common systematic factors while very little, if any, of the remaining large firm-specific variation can be explained by differences in firm size, the industry in which the firm operates, or firm-specific events. Roll, (1988) interprets the low $R^{2} \mathrm{~s}$ and the large unexplainable part of stock return variation by "existence of private information or else occasional frenzy unrelated to concrete information". Morck et al. (2000) use the $R^{2}$ as a measure of stock price synchronicity and find that in NYSE, the average $R^{2}$ of firms traded on NYSE calculated using returns from the nineties is significantly lower than that calculated using returns from the eighties, a result that is similar to the findings of Campbell et al. (2001) that $R^{2} \mathrm{~s}$ in NYSE have been decreasing over time. Morck et al. (2000) also compare the $R^{2} \mathrm{~s}$ of a large set of countries and find a significant negative correlation between the average $R^{2}$ and the country's per capita GDP. To further understand the negative relationship between price synchronicity and market development, Morck et al. (2000) regress the average $R^{2} \mathrm{~s}$ of different countries on their per capita GDPs and other variables (including economic instability, country size, economy diversification, and quality of private property rights) that per capita GDP may be a proxy for. They find that the only variable that renders per capita GDP insignificant is the extent to which the government protects private property rights and public investor rights. Thus, we hypothesize that,

H3: In a less developed country with weak investor protection, stock prices have synchronous behavior.

Extant empirical research finds that stock price synchronicity decreases as firm's governance improves. Effective corporate governance results in more firm-specific information being impounded into stock prices, thus, reduces stock price sensitivity to market-wide information. Improvements in firm's governance mechanism can result from narrower deviations between ownership and control rights, larger cash flow rights (ownership concentration) of the largest shareholder, or existence of a large shareholder(s) who has the incentive to monitor firm's management. Empirical evidence shows that the deviation between cash flow and voting rights is negatively related to synchronicity (See for example, Boubaker et al. 2014) while the evidence on the impact of ownership concentration is mixed (See for example, An and Zhang, 2013, Gul et al. 2010, Boubaker et al. 2014). Relatively little research exists on the impact of the largest shareholder's identity. The government, families, and foreign shareholders are the most common largest shareholder identities investigated in previous research. Government ownership of public firms has been found negatively related to governance quality in civil law countries (Borisova et al. 2012) and when the government is the largest shareholder, the firm's stock price synchronicity is higher (Gul et al. 2010). Foreign ownership has been found beneficial to corporations in emerging markets because foreign investors provide 
monitoring of firm's management ( $\mathrm{Li}$ et al. 2011) and their existence is inversely related to synchronicity (Gul et al. 2010). As for family-owned firms, controlling families in weak investor protection countries are usually involved in firm's management by appointing a family member and/or have, at least, one family member serving on the board of directors. This leads to aligning control and management but creates another agency problem between the controlling family as a large shareholder and minority shareholders (i.e. tunneling). Thus, controlling families become insiders and contribute firm-specific information and their trades convey such information (Piotroski and Roulstone, 2004). As a result, stock prices of family-controlled firms are expected to be less synchronous. Thus, we hypothesize that,

H4: In a country with weak investor protection, stock price synchronicity is lower when the ultimate owner is family and higher when the ultimate owner is the government.

\section{Data Construction \& Methodology}

Some of the MENA countries do not have an active capital market and even if they did, financial data are not readily available. In this paper, we use data from ASE. We were able to collect a unique data set that enables us to investigate corporate governance mechanism of a MENA country that is politically stable compared to other emerging markets including the MENA countries and has recently taken large steps towards liberalizing the economy and privatizing businesses (Note 6). It is important to note here the importance of political stability of the sample country because political risk may increase market risk leading to higher market $R^{2}$, as argued by Jin and Myers 2006.

As of 2008 there are 256 firms listed on ASE with total assets that exceed $\$ 75$ billion and market value of more than $\$ 35$ billion. For each firm, the ASE keeps record of daily closing prices, trading volume, number of transactions, financial statements data, identity of owners of $5 \%$ or more of the firm, and identity of members of board of directors. The financial statements, ownership, and board composition data are compiled once a year, so we collect the ownership and board members data at the end of 2007 whenever possible and if these data are missing, we collect it at the end of 2008 . We were able to identify the identity of owners of $5 \%$ or more, the identity of the CEO, and the identity of chairman and the vice chairman of the board of directors for 243 firms. We exclude 21 firms because their financial statement data were not available.

\subsection{How Are Firms Owned in Jordan?}

To describe how public corporations are owned in Jordan, we follow Claessens et al. (2000) in constructing direct and indirect cash flow and control rights of the controlling shareholder(s). We define cash flow rights by cash flow ownership while control rights are based on voting rights. As mentioned earlier, cash flow rights and control rights may deviate from each other if shareholders use shares with superior voting rights, pyramid structure, or cross-holdings. In Jordan, this can only happen through pyramid structure or cross-holdings because firms are not allowed to use shares with superior voting rights. We study all owners of 5\% or more of the firm' capital, and for every firm we identify the ultimate owner (controlling shareholder) using two voting rights cutoff points (10\% and $20 \%$ ). Using the $20 \%$ cutoff, a firm has a controlling owner if it has an ultimate owner whose direct and indirect voting rights in the firm are at least $20 \%$, and if there is more than one owner with more than $20 \%$ voting rights, the ultimate owner is that who has the largest total voting rights. For example, if a shareholder owns $10 \%$ of firm A which in turn owns $15 \%$ of firm B, then, the shareholder's total cash flow rights are $10 \%$ and its total voting rights are $10 \%$ in firm A. As for firm B, notice that the shareholder does not have any direct cash flow or voting rights in firm B but has indirect cash flow rights of $1.5 \%$ (the product of ownership stakes along the control chain) and indirect voting rights of $10 \%$ (the lowest ownership percentage along the control chain) in firm $\mathrm{B}$. When a shareholder has ownership stakes in multiple firms that in turn have ownership stakes in a particular firm, we add the cash flow rights along and across the control chain to calculate the shareholder's total cash flow rights and add total voting rights in similar way to calculate its voting rights. For example, if a shareholder owns $10 \%$ of firm A and $15 \%$ of firm B and firm A owns $20 \%$ of firm C and firm B owns 12\% of firm C (shown in Figure 1), then the shareholder's cash flow rights in firm $\mathrm{C}$ are $2 \%$ (the product of ownership stakes along one leg of the control chain) plus $1.8 \%$ (the product of ownership stakes along the other leg of the control chain) and the voting rights are $22 \%$ (the sum of the lowest ownership percentages along the two legs of the control chain). In this example we say that the shareholder is the ultimate owner of firm $\mathrm{C}$ and controls it through a pyramid structure under the $20 \%$ cutoff point and under the $10 \%$ cutoff point because the shareholder's voting rights in firm C exceed the $10 \%$ and $20 \%$ cutoff points. 


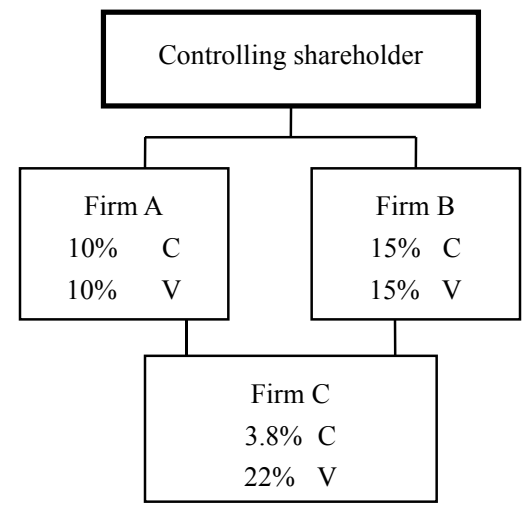

Figure 1. The principal shareholder is located on the top of the pyramid and shown in thick-bordered box. Cash flow rights are denoted with "C" and voting rights are denoted with "V".

\subsection{Examples of Ownership Structures}

To provide better insight into our data construction we present several examples of ownership structures in Jordanian publicly traded firms, some of which are simple pyramid structures in which a shareholder controls a public firm through some other public firm while others include firms that are involved in more complex ownership structures. The first example is a simple structure of pyramid ownership created by a foreign firm (Figure 2). The publicly traded Jordan Islamic Bank is the fifth largest bank in Jordan in terms of total assets and the fourth largest in terms of total market value and $57.3 \%$ of its cash flow and voting rights are directly controlled by a foreign firm, Al-Barakah Banking Group, and $16.4 \%$ are controlled by a private firm (not shown in Figure 2). Under both the $20 \%$ and $10 \%$ voting right rule, we call Al-Barakah Banking Group the ultimate owner of Jordan Islamic Bank and of all firms that are controlled by it through the Jordan Islamic Bank. Al- Barakah Banking Group controls $43 \%$ of the voting rights of the Islamic Insurance by owning only $24.6 \%$ of its shares through the Jordan Islamic Bank. The other three firms in the bottom level of Figure 2 are also controlled by Al-Barakah Banking Group in similar way but with varying cash flow ownership stakes required to control voting rights. We show later in the paper that, on average, it takes $18.2 \%$ of cash flow ownership to control $20 \%$ of the voting rights in ASE.

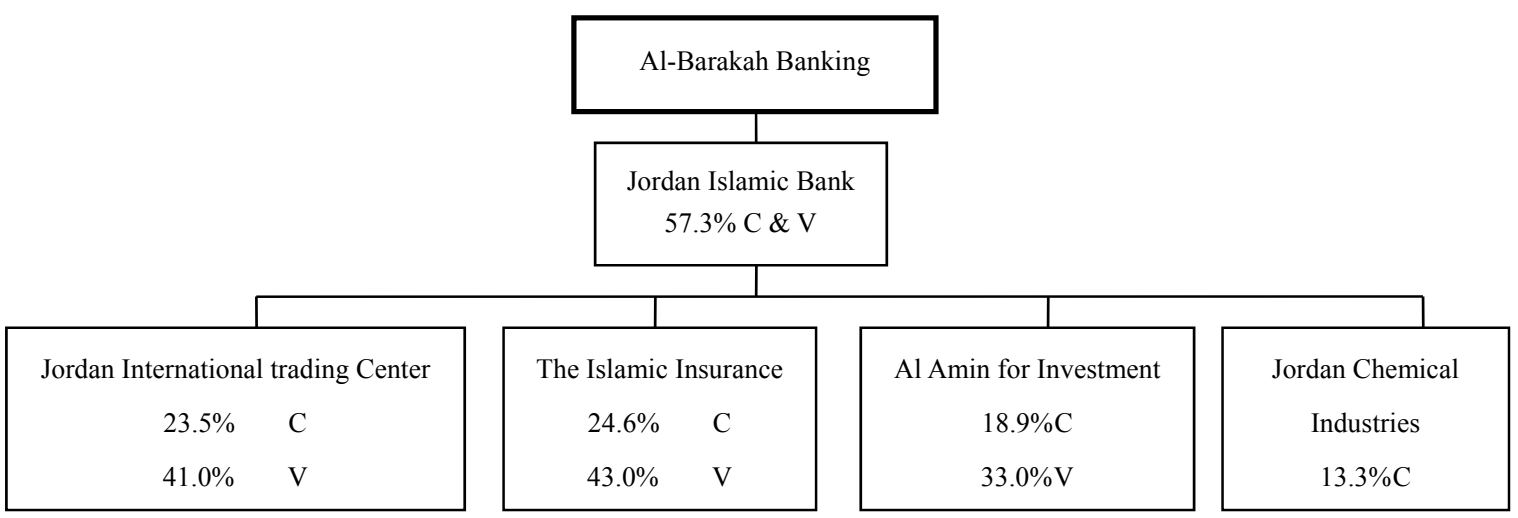

Figure 2. Al-Barakah Banking Group (Private firm). The principal shareholder is located on the top of the pyramid and shown in thick-bordered box. We call this a pyramid under the $20 \%$ rule. Cash flow rights are denoted with "C" and voting rights are denoted with "V".

The second example is a more complicated ownership structure created by the Salfiti family (Figure 3). This family directly controls $26 \%$ of the cash flow and voting rights of Specialized Investment Compounds through which it indirectly controls Al-Tajamouat for Catering and Housing. The family's voting rights in the firms Union Tobacco and Cigarettes, Union Investment Corp, and Union Bank exceed its cash flow rights not as a result of using a pyramid structure but rather because of using cross holdings between firms that are linked by dotted line. The firms Union Advanced Industries and Union for Land Development are controlled by the family through the firms located 
above them to which they are linked. Notice that cash flow ownership stake required to control voting rights decreases as we go down the pyramid, the lowest is where the family ends up controlling more than $25 \%$ of the voting rights of Union for Land Development by owning less than $5 \%$ of its cash flow rights. This is an example of firms whose ownership and control are hugely separated from each other. In cases where a firm's ultimate owner is a family, we also investigate whether the controlling family exercises its control by appointing a family member as $\mathrm{CEO}$ and/or chair or vice chair of board of directors. In fact, this is the case in the pyramid structure in Figure 3, a member of the family is the CEO and/or chairman in each and every firm controlled by the family. This is an example of a pyramid structure that results in significant separation between ownership and control but no separation between control and management.

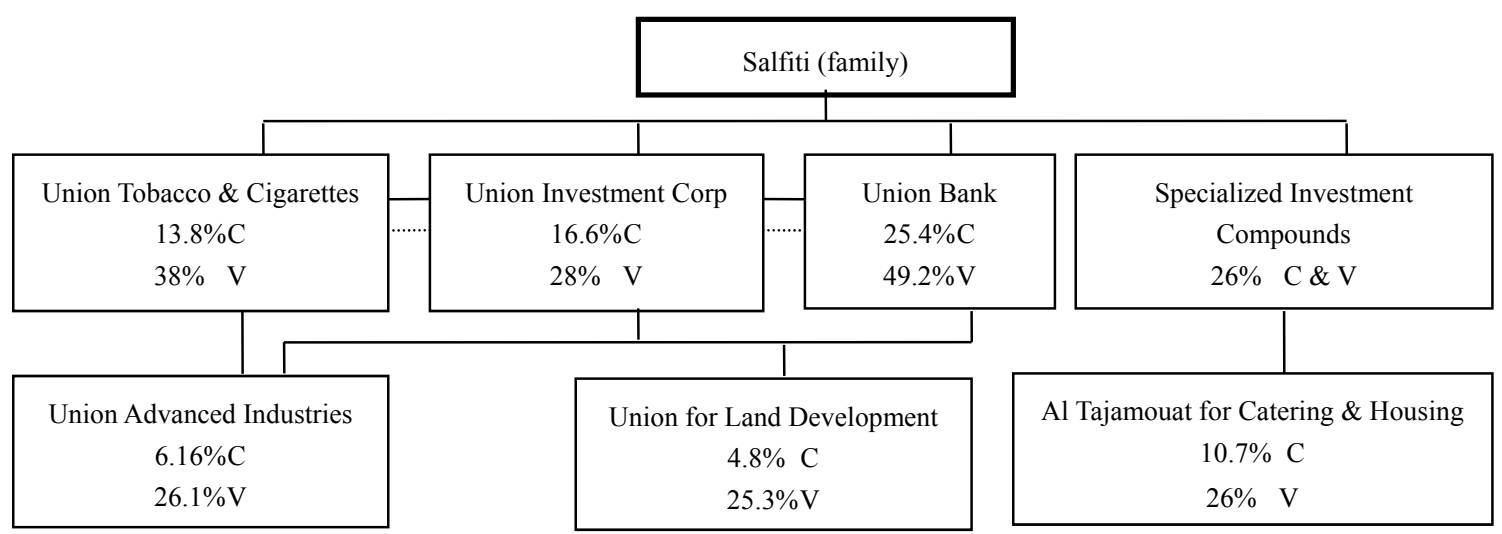

Figure 3. The Salfiti (family): The principal shareholder is located on the top of the pyramid and shown in thick-bordered box. The dotted line represents existence of cross holding between the two firms. Cash flow rights are denoted with "C" and voting rights are denoted with "V".

\section{Empirical Results}

Our investigation of the controlling shareholders and stock price behavior is based on: First, analyzing the ownership structure of corporations to determine the ultimate owner(s) or the controlling shareholder(s) and investigating whether the controlling shareholder uses its power as CEO and/or as board chair or vice chair, second, identifying any differences between cash flow rights and voting rights that controlling shareholders can create using a pyramid structure and/or cross holdings, and, third, examining stock price synchronicity in ASE.

\subsection{Determination of the Ultimate Holder of Firm's Cash Flow and Voting Rights}

To determine the ultimate owner of the corporation, we classify each and every firm of the 222 firms for which we could collect the ownership data either as widely held or controlled firm. A firm is controlled if $20 \%$ or more under the $20 \%$ cutoff point ( $10 \%$ or more under the $10 \%$ cutoff point) of its total direct and indirect voting rights are controlled by a single shareholder. A firm can have more than one single shareholder who each separately holds $20 \%$ $(10 \%)$ or more of the firm's total direct and indirect voting rights. In this case, we say that the firm is controlled by the shareholder who owns the highest total direct and indirect voting rights and later we separate firms where the controlling shareholder is alone from those where the firm's control is shared by more than one shareholder. The controlled firms are then classified into those controlled by a widely-held firm, family (where members of the same family are considered the same single shareholder), family and management, state, private firm, or foreign firm. We differentiate between two non-overlapping types of family-controlled firms: those where the controlling family participates in the firm's management by appointing one or more of the family members as CEO and/or chair or vice chair of the board of directors and those where the controlling family does not intervene in firm's management. We provide detailed definitions of all variables used in this paper in Table 1 that are similar to those used in La Porta et al. (1999). 
Table 1. Definition of the variables

\begin{tabular}{ll}
\hline \multicolumn{1}{c}{ Variable } & \multicolumn{1}{c}{ Description } \\
Widely Held & $\begin{array}{l}\text { Equals one if the firm has no controlling shareholder, and zero otherwise. } \\
\text { Equals one if the firm's controlling shareholder is a widely held firm, and zero } \\
\text { otherwise. }\end{array}$ \\
Family & $\begin{array}{l}\text { Equals one if the firm's controlling shareholder is a person, zero otherwise. A } \\
\text { person is any member of the same family. }\end{array}$ \\
Family \& Management & $\begin{array}{l}\text { Equals one if the firm's controlling shareholder is a person and the person is the } \\
\text { CEO or a member of the board of directors, and zero otherwise. }\end{array}$ \\
Private Firm & $\begin{array}{l}\text { Equals one if the firm's controlling shareholder is a private firm, and zero } \\
\text { otherwise. }\end{array}$ \\
Foreign Firm & $\begin{array}{l}\text { Equals one if the firm's controlling shareholder is a foreign firm, and zero } \\
\text { otherwise. }\end{array}$ \\
State & $\begin{array}{l}\text { Equals one if the firm's controlling shareholder is the(domestic or foreign) } \\
\text { state, and zero otherwise. }\end{array}$ \\
Controlling Shareholder & $\begin{array}{l}\text { Equals one if the firm is controlled under the 20\% cutoff and no other } \\
\text { shareholder has at least 10\% control of the firm's voting rights, and zero } \\
\text { otherwise. }\end{array}$ \\
Alone & $\begin{array}{l}\text { Equals one if the controlling shareholder exercises control through at least one } \\
\text { publicly traded firm, and zero otherwise. }\end{array}$ \\
Pyramid & $\begin{array}{l}\text { Equals one if the firm is controlled and owns shares in its controlling } \\
\text { shareholder or in a firm that belongs to its chain of control, and zero otherwise. } \\
\text { Equals one if the firm has a controlling shareholder and the controlling } \\
\text { shareholder or its representative is appointed as CEO or member of the board of } \\
\text { directors, and zero otherwise. }\end{array}$ \\
Cross-Holding &
\end{tabular}

Table 2. Classification of firms according to the type of their controlling shareholder

\begin{tabular}{cccccccc}
\hline $\begin{array}{c}\text { Widely } \\
\text { Held }\end{array}$ & $\begin{array}{c}\text { Widely Held } \\
\text { Corporation }\end{array}$ & Family & $\begin{array}{c}\text { Family \& } \\
\text { Management }\end{array}$ & State & $\begin{array}{c}\text { Private } \\
\text { Firm }\end{array}$ & $\begin{array}{c}\text { Foreign } \\
\text { Firm }\end{array}$ & $\begin{array}{c}\text { Controlling } \\
\text { shareholder } \\
\text { alone }\end{array}$ \\
\hline 0.302 & 0.054 & 0.063 & 0.306 & 0.086 & 0.036 & 0.153 & 0.369 \\
\hline Widely & $\begin{array}{c}\text { Widely Held } \\
\text { Corporation }\end{array}$ & Family & $\begin{array}{c}\text { Family \& } 10 \% \text { Cutoff } \\
\text { Management }\end{array}$ & State & $\begin{array}{c}\text { Private } \\
\text { Firm }\end{array}$ & $\begin{array}{c}\text { Foreign } \\
\text { Firm }\end{array}$ & \\
\hline 0.063 & 0.005 & 0.104 & 0.401 & 0.108 & 0.108 & 0.212 & \\
\hline
\end{tabular}

Panel A of this table classifies each firm into: widely held, controlled by widely held corporation, controlled by family, controlled by family and management, controlled by state, controlled by private firms, or controlled by foreign firms using the $20 \%$ as cutoff point for voting rights. Panel B provides similar classification using the $10 \%$ as cutoff point for voting rights. Panel A also shows the percentage of controlled firms where the controlling shareholder is alone. The definitions of all variables are as in Table 1.

Panel A of Table 2 shows that under the $20 \%$ cutoff point $36.9 \%$ of the firms traded on ASE are controlled by families and $15.3 \%$ of the firms are controlled by foreign firms while only $35.6 \%$ of them are either widely held or controlled by a widely held. In $37 \%$ of the firms controlled by a large shareholder, the controlling shareholder is alone. The controlling family's involvement in firm's management is evidenced by the observation that in more than $80 \%$ of the firms controlled by a family, the controlling family is exercising its control by appointing a family member as the CEO and/or having at least one family member serving on the board of directors. Using the $10 \%$ as the cutoff point for firm control reveals even more striking results, as shown in panel B of Table 2, where less than $7 \%$ of the firms can be classified as widely held or controlled by widely held firm. More than $60 \%$ of the firms are controlled either by a family or a private firm and family's reluctance to surrender firm's management is obvious as $40 \%$ of the firms are not only controlled by a family but also the controlling family is involved in the firm's management. Thus, reducing the cutoff point from $20 \%$ to $10 \%$ yields significant increase in percentage of firms 
controlled by a family or private firm (from $41 \%$ to $61 \%$ ) and significant decrease in percentage of firms that are widely held or controlled by a widely held firm (from $35.6 \%$ to $6.8 \%$ ). Overall, most of the Jordanian publicly traded corporations are predominantly controlled by a family or a private firm regardless of the cutoff point used to determine the percentage of controlling voting rights and in most of the firms that are controlled by a family, the controlling family is directly involved in firm's management through the CEO who is a family member and or through the board of directors where one or more of the family members serve as board member(s). These ties between the CEO and board members may weaken the effectiveness of board monitoring (Fracassi and Tate, 2012).

Because gaining cash flow rights in larger firms may be more expensive, we separate out large firms and investigate whether the above results hold for all firms or do large firms differ in terms of how they are owned and the type of their owner(s). In other words, we ask whether large firms are widely held or controlled and, if they are controlled, who owns and controls them. Therefore, we repeat the classification of firms into widely held and controlled firms for only larger firms and report the results in Table 3. Under the $20 \%$ cutoff point, $29 \%$ (6\% under the $10 \%$ cutoff point) of the large firms are widely held or controlled by widely held firm and more than $50 \%$ (more than $67 \%$ under the $10 \%$ cutoff point) of them are controlled by a family or private firm. In addition, in $40 \%$ of the large firms, the controlling shareholder is the sole controlling party of the firm. Surprisingly, family and private firm -control is more pronounced among larger firms than among small firms. One possible explanation for this observation is that the controlling families are wealthy enough to afford paying for the more expensive cash flow rights of the large firms and that the capital investments required for large firms are relatively small. In fact, Jordan's economy is small and dominated by industries that are low-tech consumer oriented whose capital requirements are relatively smaller compared to capital requirements of high-tech large value added industries.

Table 3. Classification of large firms according to the type of their controlling shareholder

\begin{tabular}{cccccccc}
\hline $\begin{array}{c}\text { Widely } \\
\text { Held }\end{array}$ & $\begin{array}{c}\text { Widely Held } \\
\text { Corporation }\end{array}$ & Family & $\begin{array}{c}\text { Family \& } \\
\text { Management }\end{array}$ & State & $\begin{array}{c}\text { Private } \\
\text { Firm }\end{array}$ & $\begin{array}{c}\text { Foreign } \\
\text { Firm }\end{array}$ & $\begin{array}{c}\text { Controlling } \\
\text { shareholder } \\
\text { alone }\end{array}$ \\
\hline 0.234 & 0.056 & 0.056 & 0.271 & 0.093 & 0.178 & 0.112 & 0.402 \\
\hline \multicolumn{7}{c}{ Panel B: 10\% Cutoff } \\
\hline Widely & $\begin{array}{c}\text { Widely Held } \\
\text { Corporation }\end{array}$ & Family & $\begin{array}{c}\text { Family \& } \\
\text { Management }\end{array}$ & State & $\begin{array}{c}\text { Private } \\
\text { Firm }\end{array}$ & $\begin{array}{c}\text { Foreign } \\
\text { Firm }\end{array}$ & \\
\hline 0.065 & 0 & 0.084 & 0.327 & 0.140 & 0.262 & 0.121 &
\end{tabular}

Panel A of this table classifies each of the large firms into: widely held, controlled by widely held, controlled by family, controlled by family and management, controlled by state, controlled by private firms, or controlled by foreign firms using the $20 \%$ as cutoff point for voting rights. Panel B provides similar classification using the $10 \%$ as cutoff point for voting rights. Panel A also shows the percentage of controlled firms where the controlling shareholder is alone. The definition of all variables is as in Table 1. A firm is classified as large if the natural logarithm of its total assets is higher than the median value of the natural logarithm of total assets for all firms.

\subsection{Prevalence of Indirect Control Mechanisms}

The identity of the controlling shareholder reported in Tables 2 and 3 has been identified by tracing the ultimate owner of the firm whose total voting rights (including the direct and indirect) exceed a particular threshold. Some of these ultimate owners gain their controlling voting rights in a particular firm through another public firm (i.e., pyramid structure) and/or through reciprocal shareholdings between the two firms (i.e., cross-shareholdings). Therefore, we investigate the use of such indirect control mechanisms in ASE and report the results in Table 4 for different groups of the firms. We separate large firms because they may require larger cash flow ownerships to gain direct voting rights which may create greater incentive for investors to attempt gaining control through indirect means. This argument is motivated by Almeida and Wolfenzon (2006), finding that a firm is less likely to be owned through a pyramid structure when it requires smaller investment. We also look at the actively traded firms separately to investigate whether the use of indirect control mechanisms signals controlling shareholder's attempts to extract private benefits, at which time the controlling shareholder may be less interested in changes in firm's stock price. Firms that are controlled by families are separated because the use of pyramid structure has been found particularly 
prevalent among firms controlled by families in many countries around the world. Other types of firms are also shown for comparison purposes.

As shown in Table 4, 25\% of the controlled firms traded on ASE are controlled through the pyramid structure where the construction of the pyramid is based on gaining at least $20 \%$ of the voting rights of the controlled firm. Similar results are also found for large firms and actively traded firms, and regardless of who controls the firm except when the firm is controlled by the state at which time it becomes more thantwice as likely to be controlled through another publicly traded firm (57\% of the firms controlled by the state are controlled through a pyramid structure) and when the firm is controlled by a private firm where only $16 \%$ of them are controlled through the pyramid structure. Family-controlled firms exhibit significant involvement of the controlling family in firm's management where in $90 \%$ of the them a family member is appointed as the CEO andlor is a member of the board of directors, indicating loose separation between ownership and management in such firms (Note 7). We do not find that the use of the pyramid structure or the separation between ownership and control is particularly prevalent in family-controlled firms. The use of cross-holding, on the other hand, seems to be very rare. However, it should be noted here that the reciprocal shareholdings between firms that we report in Table 4 do not include those that are outside firm's control chain.

Table 4. The prevalence of pyramid structure and cross-holdings for different classification of firms

\begin{tabular}{lcccc}
\hline \multicolumn{1}{c}{ Type of firm } & $\begin{array}{c}\text { Number of } \\
\text { corporations }\end{array}$ & Pyramid & Cross-holding & Management \\
\hline All controlled firms & 155 & 0.250 & 0.038 & \\
Large controlled firms & 83 & 0.265 & 0.072 & \\
Controlled and actively traded firms & 82 & 0.250 & 0.061 & 0.902 \\
Family-controlled firms & 82 & 0.240 & 0.080 & 0.750 \\
Private-firm controlled firms & 8 & 0.156 & 0 & 0789 \\
State-controlled firms & 19 & 0.570 & 0 & 0.882 \\
Foreign-firm controlled firms & 34 & 0.25 & 0 & \\
\hline
\end{tabular}

This table classifies the groups of firms shown in the first column into those that are controlled though a pyramid, involved in cross holdings with another firm in its control chain. For family-controlled firms, it shows the percentage of firms where the family is involved in firm's management. The definition of the variables is as in Table 1.

The use of indirect control mechanisms would benefit the controlling shareholders if they resulted in deviations between ownership and control because it makes it less costly for shareholders to control a public firm by gaining majority voting rights with less ownership of cash flow rights. To investigate the extent to which the use of such mechanisms results in these deviations, we replicate Claessens et al. (2000) analysis in Table 5 where we show the descriptive statistics for the cash flow rights, voting rights, and the ratio of cash flow to voting rights. This is done using ownerships of at least $10 \%$ for both the cash flow and voting rights. In table 5, we calculate the cash flow rights, voting rights, and the extent to which they are separated from each other for firms classified by their controlling shareholder. The largest cash flow rights as well as voting rights concentration is in firms controlled by foreign firms $(40.28 \%$ and $43.60 \%$, respectively) and the smallest are in family- controlled firms $(25.19 \%$ and $28.39 \%$, respectively).

Regardless of who controls the firm, about 9 shares are needed to gain 10 voting rights except when the firm is controlled by the state where a little more than 8 shares are enough to gain 10 voting rights. Noticeably, $25 \%$ of the firms controlled by foreign firms or the state need less than 8 shares to gain 10 voting rights.

\subsection{Measures of Stock Price Synchronicity}

Following Morck et al. (2000) we use two measures of stock price synchronicity. The first one is the frequency of price changes in the same direction calculated as follows:

$$
f_{t}=\frac{\max \left[n_{t}^{u p}, n_{t}^{\text {down }}\right]}{n_{t}^{u p}+n_{t}^{\text {down }}}
$$

Where $n_{t}^{u p}$ is number of stocks whose prices go up and $n_{t}^{\text {down }}$ is number of stocks whose prices go down in period $t$. The value of this equation will be equal to 0.5 if $50 \%$ of stocks prices move in one direction and the other $50 \%$ 
move in the opposite direction, and will be equal to 1 if the prices of all stocks move in the same direction, otherwise it will be somewhere between 0.5 and 1 .

Stock price synchronicity implies that stocks are more sensitive to factors that are common among all firms (market-wide factors). Therefore, another measure of price synchronicity is the percentage of stock price changes that can be explained by sensitivity to market factors or the $R^{2}$ from the linear market model of the form,

$$
R_{i t}=\alpha_{i}+\beta_{i} R_{m t}+\varepsilon_{i t}
$$

Where $R_{i t}$ is stock $i$ 's return in time period $t$ and $R_{m t}$ is the market index return. We use different specifications and proxies for the market portfolio to account for the sensitivities of the stock price not only to local but also global markets. A high $R^{2}$ of this regression indicates high synchronicity. Because $R^{2}$ is bounded by zero and one, we follow Morck et al. (2000) and apply a logistic transformation. Therefore, this synchronicity measure becomes

$$
S Y N C H=\log \left(\frac{R^{2}}{1-R^{2}}\right)
$$

Table 5. Separation of ownership and voting rights for firms classified according to their controlling shareholder

\begin{tabular}{lcccccc}
\hline \multicolumn{1}{c}{ Type of controlling shareholder } & $\begin{array}{c}\text { Number } \\
\text { of firms }\end{array}$ & Mean & Median & $\begin{array}{c}\text { Standard } \\
\text { deviation }\end{array}$ & $\begin{array}{c}1^{\text {st }} \\
\text { quartile }\end{array}$ & $\begin{array}{c}3^{\text {rd }} \\
\text { quartile }\end{array}$ \\
\hline $\begin{array}{l}\text { A. Cash flow rights } \\
\text { Family }\end{array}$ & 102 & 25.19 & 21.35 & 15.94 & 14.00 & 33.00 \\
Foreign firm & 19 & 40.28 & 38.00 & 26.29 & 17.50 & 55.00 \\
Private firm & 59 & 30.22 & 20.00 & 23.60 & 14.00 & 42.00 \\
State & 24 & 26.19 & 19.35 & 22.16 & 11.04 & 34.59 \\
& & & & & & \\
B. Voting rights & 107 & 28.39 & 25.6 & 14.61 & 18.00 & 34.00 \\
Family & 19 & 43.60 & 44.00 & 24.26 & 24.0 & 55.00 \\
Foreign firm & 59 & 32.67 & 23.20 & 22.26 & 15.00 & 43.00 \\
Private firm & 24 & 31.80 & 23.84 & 22.14 & 15.82 & 40.17 \\
State & & & & & & \\
& & & & & & \\
C. Ratio of cash flow rights to voting rights & & & & & & \\
Family & 107 & 0.88 & 1.00 & 0.25 & 1.00 & 1.00 \\
Foreign firm & 19 & 0.88 & 1.00 & 0.22 & 0.75 & 1.00 \\
Private firm & 59 & 0.89 & 1.00 & 0.24 & 1.00 & 1.00 \\
State & 24 & 0.81 & 0.90 & 0.24 & 0.71 & 1.00 \\
\hline
\end{tabular}

This table shows the cash flow and voting rights are calculated using ownerships of the largest shareholder of, at least, $10 \%$. Excluded from the full sample are 28 firms where the largest shareholder holds less than $10 \%$ of the firm's capital.

Table 6 shows the percentage of firms whose prices went up, down, or stayed the same, where the change in price is calculated using weekly closing prices instead of daily prices in order to minimize nontrading bias. In 16 of the 52 weeks, $60 \%$ or more of stocks moved in the same direction and in six (one) of the 52 weeks $70 \%$ or more of stocks moved down (up) while less than $20 \%$ of them moved up (down). The second half of 2008 witnessed larger difference between the percentage of firms whose prices move up and down, more specifically, the percentage of stocks moving down (up) in a given week is larger (smaller) in the second half of 2008 than in the first half. Yet, we recognize that the adverse impacts of the global economic recession following the U.S financial crisis in early 2008 may have contributed to widening those differences in ASE during the second half of 2008. To get feel of the severity of those impacts, we examined the stock price behavior in previous years and found similar pattern of difference between percentage of stocks going up and down although it appears to be little larger in the second half of 2008. Therefore, the possibility that larger percentage of firms whose prices experience negative price changes may be confined to economic recessionary times can be ruled out. However, if, in Jordan, the higher synchronicity is associated with higher market variation as found by Morck et al. (2000) in emerging markets and if this higher market variation incorporates more market information as shown by Chan and Hameed (2006), then the obvious larger differences between the percentage of stocks going up or down in the second half of 2008 may be due to the availability of more market-wide information to investors during economic recessionary times. 
Table 6. Percentage of firms whose prices move up, down, or stay the same in the week shown in the first column for the year 2008

\begin{tabular}{|c|c|c|c|}
\hline Week & $\% \mathrm{Up}$ & \%Down & \%Same \\
\hline 1 & 61 & 25 & 14 \\
\hline 2 & 38 & 51 & 11 \\
\hline 3 & 39 & 49 & 12 \\
\hline 4 & 22 & 66 & 12 \\
\hline 5 & 50 & 29 & 21 \\
\hline 6 & 39 & 49 & 12 \\
\hline 7 & 47 & 38 & 15 \\
\hline 8 & 36 & 52 & 12 \\
\hline 9 & 41 & 47 & 12 \\
\hline 10 & 33 & 54 & 13 \\
\hline 11 & 49 & 39 & 12 \\
\hline 12 & 24 & 62 & 14 \\
\hline 13 & 28 & 57 & 15 \\
\hline 14 & 41 & 47 & 12 \\
\hline 15 & 45 & 36 & 19 \\
\hline 16 & 34 & 52 & 14 \\
\hline 17 & 41 & 46 & 13 \\
\hline 18 & 32 & 50 & 18 \\
\hline 19 & 47 & 37 & 16 \\
\hline 20 & 35 & 52 & 13 \\
\hline 21 & 47 & 38 & 15 \\
\hline 22 & 43 & 39 & 18 \\
\hline 23 & 58 & 30 & 12 \\
\hline 24 & 45 & 48 & 7 \\
\hline 25 & 47 & 44 & 9 \\
\hline 26 & 24 & 67 & 9 \\
\hline 27 & 56 & 31 & 13 \\
\hline 28 & 20 & 68 & 12 \\
\hline 29 & 35 & 54 & 11 \\
\hline 30 & 47 & 34 & 19 \\
\hline 31 & 37 & 49 & 14 \\
\hline 32 & 28 & 59 & 13 \\
\hline 33 & 33 & 52 & 15 \\
\hline 34 & 11 & 77 & 12 \\
\hline 35 & 72 & 16 & 12 \\
\hline 36 & 30 & 56 & 14 \\
\hline 37 & 16 & 69 & 15 \\
\hline 38 & 36 & 49 & 15 \\
\hline 39 & 40 & 42 & 18 \\
\hline 40 & 52 & 21 & 27 \\
\hline 41 & 7 & 80 & 13 \\
\hline 42 & 33 & 54 & 13 \\
\hline 43 & 8 & 80 & 12 \\
\hline 44 & 34 & 54 & 12 \\
\hline 45 & 61 & 29 & 10 \\
\hline 46 & 17 & 73 & 10 \\
\hline 47 & 18 & 71 & 11 \\
\hline 48 & 21 & 65 & 14 \\
\hline 49 & 63 & 26 & 11 \\
\hline 50 & 48 & 38 & 14 \\
\hline 51 & 24 & 61 & 15 \\
\hline 52 & 30 & 50 & 20 \\
\hline
\end{tabular}

On average, the prices of approximately $14 \%$ of the firms listed on ASE do not change in a typical week. Like most of the emerging markets, the trading in ASE is thin so it is possible that some stocks' prices may not have changed because they were not traded on daily basis. The trading data of ASE reveals that in a typical day, on average, only 
175 out of 256 firms listed on ASE are traded which leaves about $25 \%$ of firms not traded. Thus, there is more market thinness than what using weekly returns can eliminate Therefore, the percentages shown in Table 6 are calculated using only those firms that are actually traded in the particular week in order to further reduce nontrading bias. To formally measure stock price synchronicity, we calculate the percentage of stocks whose prices move in the same direction in every day or week using equation (1), $f_{t}$, which excludes stocks whose prices did not change in a given day or week. Table 7 reports the summary statistics for $f_{t}$ and shows that, on average, about $65 \%$ of stocks move in the same direction in a given day or week and differentiating between daily and weekly price changes does not change this result.

Table 7. Descriptive statistics of the frequency of same direction stock price changes and of the $R^{2}$ from the linear market model

\begin{tabular}{cccccc}
\hline & Mean & Median & Standard deviation & Min & Max \\
\hline$f_{t}$ (daily) & 0.649 & 0.620 & 0.114 & 0.500 & 0.945 \\
& & & & \\
$f_{t}$ (weekly) & 0.647 & 0.620 & 0.108 & 0.511 & 0.922 \\
& & & & \\
$R_{d}^{2}$ & 0.204 & 0.181 & 0.131 & 0.008 & 0.611 \\
$R_{e}^{2}$ & 0.281 & 0.282 & 0.140 & 0.022 & 0.569 \\
$R_{f}^{2}$ & 0.238 & 0.213 & 0.156 & 0.012 & 0.883 \\
$R_{h}^{2}$ & 0.201 & 0.182 & 0.129 & 0.008 & 0.600 \\
\hline
\end{tabular}

The frequency of same direction stock price changes are calculated as,

$$
f_{t}=\frac{\max \left[n_{t}^{u p}, n_{t}^{\text {down }}\right]}{n_{t}^{u p}+n_{t}^{\text {down }}}
$$

Where $\mathrm{n}_{\mathrm{t}}^{\text {up }}$ is number of stocks whose prices go up and $n_{t}^{\text {down }}$ is number of stocks whose prices go down in period $\mathrm{t}$. The $R^{2} \mathrm{~s}$ are from the linear market model of the form:

$$
R_{i t}=\alpha_{i}+\beta_{i} R_{m t}+\varepsilon_{i t}
$$

using several specifications for the market model and several proxies for the market portfolio. $R_{d}^{2}$ uses the local market-value weighted index, $R_{e}^{2}$ uses local market-value weighted index and controls for lagged market portfolio return, $R_{f}^{2}$ uses the local market-value weighted index and controls for lagged market portfolio return, sensitivity to industry, and return on lagged industry portfolio, $R_{h}^{2}$ uses the local market-value weighted index and includes the market-value weighted NYSE composite index.

The second measure of price synchronicity is based on the $R^{2}$ from the market model. In Table 7, we report the $R^{2}$ results calculated using several specifications of the market model that include the sensitivity not only to local market but also to the global market with different proxies for the local and global market portfolios. The first three specifications use the market value weighted local market index as a proxy for the market portfolio, control for lagged change in market portfolio return, and control for sensitivity to industry specific factors and lagged changes in industry-specific factors, respectively. In the last specification, we also control for the sensitivity of firms to changes in the global market using the market value weighted NYSE composite index as proxy for global market portfolio. To provide reliable values of the $R^{2} \mathrm{~s}$, we require that the firm has been traded for, at least, 200 days in 2008. Only 132 firms of the 222 firms that were traded in 2008 satisfy this condition due to the thin trading in ASE. These 132 corporations account for about $92 \%$ and $89 \%$ of the total assets and total market value of the whole market, respectively.

As shown in Table 7, the mean values of $R^{2}$ across the different specifications range from $20 \%$ to $28.1 \%$ and are not statistically different from their median values which means that $R^{2} \mathrm{~s}$ are symmetrically distributed. However, these $R^{2}$ s should be taken with some caveat because the $R^{2}$ value from the market model may be a function of 
many factors including firm size, type of industry in which the firm operates, and the extent to which the firm is diversified assuming that the market index used as proxy for the market portfolio is itself well diversified. Here, we focus on firm size as more important factor in determining firm's return variation explained by market movements because in emerging markets with relatively small and more concentrated economies like Jordan whose GDP in 2008 was about $\$ 21.2$ billion, firm size may proxy for its contribution to the country's economy rather than being a proxy for the extent to which the firm may be diversified as in developed markets. If this is the case, then, larger firms are likely to have higher $R^{2}$ because they shape and perhaps even lead the market movements. This argument is motivated by findings of prior research that market returns can be predicted by returns of industries that are correlated with measures of economic activity such as production growth and inflation in both U.S and non U.S markets (Hong et al. 2007) and the evidence that stock returns contain cross-autocorrelations where large stocks' returns lead those of small stocks (Lo and Mackinaly, 1990).

To investigate any possible association between $R^{2}$ and firm size; we divide the firms into two groups based on their size. A firm is classified as large (small) if the natural logarithm of its total assets is higher (lower) than the median value of the natural logarithm of total assets for all firms. As shown in Table $8, t$-tests of the mean differences and Wilcoxon signed rank tests of the median differences show that both the mean and median values of $R^{2}$ for large firms across all of the specifications used are significantly higher than those for small firms. Therefore, we conclude that firm size is an important variable across which firms' exposure to market conditions is systematically different and that any possible explanations of stock price synchronicity in emerging markets need to control for it.

Table 8 . Tests of differences in stock price synchronicity between large and small firms

\begin{tabular}{|c|c|c|c|c|c|c|}
\hline & \multicolumn{2}{|c|}{$\begin{array}{c}\text { Small firms } \\
(<\text { Median Size })\end{array}$} & \multicolumn{2}{|c|}{$\begin{array}{c}\text { Large firms } \\
(>\text { Median Size) }\end{array}$} & \multicolumn{2}{|c|}{ Difference } \\
\hline & Mean & Median & Mean & Median & Mean & Median \\
\hline$R_{d}^{2}$ & 0.1675 & 0.1417 & 0.2423 & 0.2463 & $0.0748^{\mathrm{a}}$ & 0.1046 \\
\hline$R_{e}^{2}$ & 0.2393 & 0.2210 & 0.3248 & 0.3509 & $0.0855^{\mathrm{a}}$ & $0.1299^{\mathrm{a}}$ \\
\hline$R_{f}^{2}$ & 0.1922 & 0.1842 & 0.2870 & 0.2672 & $0.0948^{\mathrm{a}}$ & $0.0830^{\mathrm{a}}$ \\
\hline$R_{h}^{2}$ & 0.1675 & 0.1482 & 0.2369 & 0.2403 & $0.0694^{\mathrm{a}}$ & $0.0921^{\mathrm{a}}$ \\
\hline
\end{tabular}

$t$-tests of mean difference and Wilcoxon rank tests of median difference between large and small firms of the $R^{2}$ from the linear market model. $R^{2} S$ are as defined earlier. ${ }^{\mathrm{a}, \mathrm{b}}$ Significant at $1 \%$ and $5 \%$ confidence levels, respectively.

Thus far we have established that stock prices in Jordan are synchronous and that, on average, $25 \%$ of changes in returns are explained by changes in market conditions. Morck et al. (2000) find that these findings characterize countries with low per capita GDP and that the lower a country's per capita GDP, the more synchronous are its stock prices. They show that countries with low per capita GDP have poor investor rights protection laws that are weakly enforced resulting in minority shareholders' rights being less protected. La Porta et al. (1997) find that minority shareholders' rights are less protected in French origin civil-law countries than in English origin common-law countries. Jordan is a French origin civil-law country with relatively low per capita GDP and the quality of its investor protection laws and their enforcement have been investigated previously. For example, La Porta et al. 1998 found that Jordan scored 1 out of 5 on the antidirector index indicating poor investor protection laws and scored less than the average values among countries that use the civil law on measures of law enforcement indicating that the already poor investor protection laws are weakly enforced. Also, La Porta et al. (2006) found that Jordan scored 0.22, 0.33 , and 0 out of 1 on liability standard, supervisor characteristics, and criminal sanctions, respectively, as measures of public enforcement of laws. All of these measures are lower than their averages for civil-law countries and although Jordan scored higher than the average on overall public enforcement measure, it is still lower than the average score of public enforcement for common-law countries. Again, this indicates that law enforcement in Jordan is weak.

\subsection{Ultimate Owners and Stock Price Synchronicity}

In this section, we investigate whether the identity of the largest shareholder is related to stock price synchronicity. We present the $R^{2}$ s for the 132 firms that are actively traded and either widely held or controlled, using both the $20 \%$ and the $10 \%$ cutoff points for the controlling percentage of voting rights, in panels B and D of Table 9 , 
respectively. First, we find that $39.6 \%$ of the firms are controlled by families or private firms and $42.6 \%$ of the firms are either widely held or controlled by a public firm using $20 \%$ as cutoff point for controlling voting rights (panel A). These numbers are $71.3 \%$ and $7.0 \%$, respectively, using $10 \%$ as cutoff point (panel C). We use the median difference rather than the mean difference tests to compare the $R^{2} \mathrm{~s}$ of the firms controlled by a particular shareholder to those of the widely held or public firm- controlled firms because the number of controlled firms across the different types of controlling shareholder varies widely, in particular, firms that are controlled by the state or a foreign firm are relatively few. The widely held or public firm-controlled firms' group is used as the benchmark group because such firms' stock prices cannot be expected to be affected by the incentives of a particular shareholder or group of shareholders. In panel $\mathrm{B}$, the Wilcoxon rank test shows that family controlled firms have significantly lower $R^{2} \mathrm{~s}$, at the $10 \%$ significance level, than those of the widely held firms when the proxy used for the market portfolio is the market-value weighted index. Firms that are controlled by the state are more susceptible to market conditions than widely held firms. The results in panel D also show that stock prices of family controlled firms are less synchronous than those of widely held firms while stock prices of state- controlled firms are as synchronous as those of the widely held firms. Based on these results we can state that the identity of the controlling shareholder does not matter as far as stock price synchronicity is concerned except when the firm is controlled by a family. Stock prices of family controlled firms seem to be systematically less synchronous than those of widely held firms or firms controlled otherwise.

Table 9. Tests of differences in stock price synchronicity among firms classified according to their controlling shareholder

\begin{tabular}{|c|c|c|c|c|c|c|c|c|c|c|}
\hline & \multicolumn{2}{|c|}{ Family } & \multicolumn{2}{|c|}{$\begin{array}{l}\text { Widely-held or } \\
\text { controlled by } \\
\text { public firm }\end{array}$} & \multicolumn{2}{|c|}{ Private firm } & \multicolumn{2}{|c|}{ Foreign } & \multicolumn{2}{|c|}{ State } \\
\hline \multicolumn{11}{|l|}{ Panel A: } \\
\hline \# of obs & \multicolumn{2}{|c|}{34} & \multicolumn{2}{|c|}{59} & \multicolumn{2}{|c|}{17} & \multicolumn{2}{|c|}{11} & \multicolumn{2}{|c|}{11} \\
\hline $\begin{array}{l}\% \text { of } \\
\text { total }\end{array}$ & \multicolumn{2}{|c|}{26.4} & \multicolumn{2}{|c|}{42.6} & \multicolumn{2}{|c|}{13.2} & \multicolumn{2}{|c|}{9.3} & \multicolumn{2}{|c|}{8.5} \\
\hline & Mean & Median & Mean & Median & Mean & Median & Mean & Median & Mean & Median \\
\hline \multicolumn{11}{|l|}{ Panel B: } \\
\hline$R_{d}^{2}$ & 0.152 & $0.128^{c}$ & 0.198 & 0.210 & 0.244 & 0.241 & 0.255 & .0200 & 0.270 & $0.255^{c}$ \\
\hline$R_{e}^{2}$ & 0.233 & 0.195 & 0.281 & 0.303 & 0.301 & 0.367 & 0.317 & 0.318 & 0.351 & $0.357^{c}$ \\
\hline$R_{f}^{2}$ & 0.177 & $0.145^{c}$ & 0.232 & 0.235 & 0.291 & 0.322 & 0.300 & 0.245 & 0.303 & $0.276^{\mathrm{c}}$ \\
\hline$R_{h}^{2}$ & 0.150 & $0.121^{\mathrm{c}}$ & 0.197 & 0.199 & 0.236 & 0.231 & 0.247 & 0.192 & 0.267 & $0.255^{\mathrm{c}}$ \\
\hline \multicolumn{11}{|l|}{ Panel C: } \\
\hline \# of obs & \multicolumn{2}{|c|}{55} & \multicolumn{2}{|c|}{9} & \multicolumn{2}{|c|}{37} & \multicolumn{2}{|c|}{13} & \multicolumn{2}{|c|}{15} \\
\hline $\begin{array}{l}\% \text { of } \\
\text { total }\end{array}$ & \multicolumn{2}{|c|}{42.6} & \multicolumn{2}{|c|}{7.00} & \multicolumn{2}{|c|}{28.7} & \multicolumn{2}{|c|}{10.1} & \multicolumn{2}{|c|}{11.6} \\
\hline \multicolumn{11}{|l|}{ Panel D: } \\
\hline$R_{d}^{2}$ & 0.164 & $0.129^{c}$ & 0.225 & 0.248 & 0.199 & 0.185 & 0.244 & 0.178 & 0.310 & 0.268 \\
\hline$R_{e}^{2}$ & 0.245 & $0.206^{\mathrm{a}}$ & 0.358 & 0.385 & 0.265 & $0.233^{c}$ & 0.307 & 0.281 & 0.375 & 0.357 \\
\hline$R_{f}^{2}$ & 0.188 & $0.150^{\mathrm{b}}$ & 0.273 & 0.262 & 0.240 & 0.235 & 0.287 & 0.223 & 0.351 & 0.277 \\
\hline$R_{h}^{2}$ & 0.163 & 0.125 & 0.227 & 0.247 & 0.195 & 0.180 & 0.235 & 0.175 & 0.309 & 0.265 \\
\hline
\end{tabular}

Panel A and C classify the actively traded firms by their controlling shareholder using the $20 \%$ and $10 \%$ cutoff points, respectively. Panels B and D show the mean and median values of $R^{2}$ for group of firms using the $20 \%$ and $10 \%$ cutoff points, respectively. All variables are as defined earlier. ${ }^{\mathrm{a}, \mathrm{b}, \mathrm{c}}$ Significant at $1 \%, 5 \%$, and $10 \%$ confidence levels, respectively. 
In Table 10, we investigate the association between largest shareholder's identity and stock price synchronicity. The identity of the largest shareholder is measured as dummy variable that is equal to one if the largest shareholder is the government, family, or foreign. The dependent variable in all models is the synchronicity calculated as in equation (3). To calculate the $R^{2}$, Model (1) uses the market-value weighted market return, Model (2) adds the lagged market portfolio return, Model (3) further controls for industry- specific factors by adding industry portfolio return and lagged industry return, and Model (4) uses the market-value weighted market return and controls for sensitivity to global market by adding the return on market-value weighted NYSE composite index. We control for firm's size because larger firms may have more firm-specific information available to investors than small firms. Also, we control for stock price volatility, leverage, and the ratio of market value to book value of equity. The results show that firms controlled by the government are significantly more synchronous than widely-held firms while firms controlled by families are less synchronous. However, the significance level for the family-controlled firms is $10 \%$. For firms that are controlled by foreign investors, the parameter estimate is insignificant indicating that these firms' stock prices behave like those of widely-held firms.

Table 10. The association between stock price synchronicity and largest shareholder's identity

\begin{tabular}{|c|c|c|c|c|}
\hline Variable & Model (1) & Model (2) & Model (3) & Model (4) \\
\hline Constant & $-3.204^{\mathrm{a}}$ & $-3.042^{a}$ & $-3.226^{\mathrm{a}}$ & $-2.993^{\mathrm{a}}$ \\
\hline Size & $0.370^{\mathrm{a}}$ & $0.344^{\mathrm{a}}$ & $0.378^{\mathrm{a}}$ & $0.340^{\mathrm{a}}$ \\
\hline Volatility & $0.035^{\mathrm{b}}$ & $0.030^{\mathrm{b}}$ & $0.030^{\mathrm{b}}$ & $0.318^{b}$ \\
\hline Leverage & $-0.851^{a}$ & $-0.670^{a}$ & $-0.726^{a}$ & $-0.725^{a}$ \\
\hline $\mathrm{M} / \mathrm{B}$ & $-0.140^{c}$ & -0.110 & -0.051 & $-0.129^{c}$ \\
\hline Family & -0.102 & $-0.127^{c}$ & $-0139^{c}$ & $-0.117^{c}$ \\
\hline Foreign & 0.042 & 0.093 & 0.088 & 0.087 \\
\hline State & $0.288^{\mathrm{a}}$ & $0.251^{\mathrm{a}}$ & $0.233^{b}$ & $0.267^{\mathrm{a}}$ \\
\hline $\mathrm{R}^{2}$ & 0.24 & 0.30 & 0.31 & 0.29 \\
\hline
\end{tabular}

The dependent variable in all models is stock price synchronicity measured as

$$
S Y N C H=\log \left(\frac{R^{2}}{1-R^{2}}\right)
$$

Size is firm's size measured as the natural logarithm of firm's total assets. Volatility is the standard deviation of daily stock returns. Leverage is the firm's total liabilities divided by total assets. M/B is firm's market-to-book ratio calculated as the market value of equity divided by the book value of equity. Family is a dummy variable that is equal to 1 if the firm's largest shareholder is family and 0 otherwise. Foreign is dummy variable that is equal to 1 if the largest shareholder is foreign firm and 0 otherwise. State is dummy variable that is equal to 1 if the firm's largest shareholder is the government and 0 otherwise. T-statistics are calculated using White Heteroskedasticity robust standard errors. ${ }^{\mathrm{a}, \mathrm{b}, \mathrm{c}}$ denote significance at the $1 \%, 5 \%$, and $10 \%$ levels, respectively.

\section{Conclusions}

High stock price synchronicity has been a distinguishing feature of countries with weak investor protection laws and less developed capital markets (Morck et al. 2000 and Campbell et al. 2001). From legal perspective, laws of French-origin civil law countries are weak in terms of minority shareholders protection compared to those of English-origin common law countries where laws are also better enforced (La Port et al. 1997). From financial point of view, the quality of investor protection manifests itself through the extent to which firm's ownership is concentrated in the hands of few shareholders (controlling shareholders) where more concentration is observed in countries with weak investor protection (La Porta et al. 2006). Firm's ownership and control become aligned when the firm is directly owned by a single (few) shareholder (s) using shares with single voting right, at which time no deviation between ownership and control exists. Ownership and control deviate from each other when the firm is owned using shares with superior voting rights or through indirect mechanisms (i.e., constructing pyramids, or cross-holdings among firms). In this paper, we investigate both the way public corporations are owned and controlled and the association between stock price synchronicity and the identity of the largest shareholder in a country with weak investor protection (namely, Jordan). Jordan is one of the MENA countries from where research is limited.

We find that stock prices in Jordan are synchronous and even more so for large firms, albeit not as synchronous as they are in other emerging markets. Most of the publicly traded corporations in Jordan, especially large corporations, 
are directly owned and controlled by families or private firms. Moreover, most of the firms that are controlled by families are also managed by it and/or have at least one family member on their board of directors. One out of every four corporations is controlled through, at least, another publicly traded firm using $10 \%$ as the cutoff point for controlling percentage of voting rights. The use of indirect control mechanisms (i.e., pyramid structure and cross-holdings) is as common among family controlled firms as it is among firms that are controlled by other types of shareholders and results in only marginal deviation between ownership and control (the controlling shareholder can gain 10 voting rights by owning little less than 9 shares). This result holds for all firms whether the firm was large or actively traded or not and regardless of who controls the firm. However, large (family controlled) firms exhibit the largest (smallest) concentration of ownership and control rights.

In conclusion, our analysis is far from complete and several relevant issues remain unexplored in the MENA region in general and in Jordan in particular. These issues include: First and foremost, the legal framework that governs how firms are owned, controlled, and managed remains the most important aspect in determining the quality of public investor rights protection. Having good minority shareholder protection laws is essential as the quality of investor protection is positively related to firm value (La Porta et al., 2000), corporate risk taking and firm growth rates (John et al. 2008), and efficiency of capital allocation (Wrugler, 2000). Also, it enhances accurate stock price, encourages efficient investment and reduces financial constraints (Mclean et al. 2011), enhances stock liquidity (Brockman and Chung, 2003), and limits extraction of firm value by firm's controlling shareholders and managers (Atanasov et al. 2010). Therefore, it is necessary to investigate how the legal corporate governance mechanism can be improved by pointing out existing laws' merits and loopholes in terms of their ability to protect minority shareholders. Second, under the $20 \%$ cutoff point about $60 \%$ of all firms and more than $70 \%$ of the large firms are controlled firms and about $37 \%$ and $40 \%$ of all firms and large firms, respectively, are controlled by only one shareholder. This means that in more than half of the controlled firms, firm's control is shared by more than one shareholder. Although the role that this shared control may have in providing monitoring of firm's management is noted in previous research, further research is needed to understand its implications in the MENA region. Third, we find that firms controlled by families are significantly less synchronous than widely held firms, but whether this lower synchronicity is due to lower sensitivity to market-wide factors or to higher firm-specific risk remains unanswered question. Therefore, further research is needed to investigate the relationship between the quality of public investor protection and firm-specific variation in stock price changes. We could not do this here because our analysis includes only one country and all corporations are subject to the same laws. Hence, it would be interesting to provide cross-country comparisons among MENA countries in terms of their investor protection quality and firm-specific variation in stock price changes. Fourth, we did not investigate why family firms are less synchronous than widely held firms nor did we investigate what motivates the family to control the firm. Less synchronous behavior of family controlled firms' stock prices may be the result of controlling families extracting private benefits with no concern of stock prices changes or may be that their prices reflect more firm-specific risk. Disentangling these two effects remains a research question. Finally, it is important to understand what impedes firm-specific information from being incorporated into stock prices in emerging markets including the MENA market. Stock prices that contain more firm-specific information are better predictors of future earnings (Durnev et al. 2003), enhance efficient allocation of wealth (Wrugler, 2000), and are positively related to efficient corporate investment (Durnev et al. 2004).

\section{References}

Almeida, H., \& Wolfenzon, D. (2006, December). A Theory of Pyramidal Ownership and Family Business Groups. Journal of Finance, 61(6), 2637-2680. http://dx.doi.org/10.1111/j.1540-6261.2006.01001.x

An, H., \& Zhang, T. (2013). Stock Price Synchronicity, Crash Risk, and Institutional Investors. Journal of Corporate Finance, 21, 1-15. http://dx.doi.org/10.1016/j.jcorpfin.2013.01.001

Atanasov, V., Black, B., Ciccotello, C., \& Gyoshev, S. (2010). How Does Law Affect Finance? An Examination of Equity Tunneling in Bulgaria. Journal of Financial Economics, 96, 155-173. http://dx.doi.org/10.1016/j.jfineco.2009.12.005

Black, B. S., de Carvalho, A. G., \& Gorga, E. (2012, September). What Matters and for Which Firms for Corporate Governance in Emerging Markets? Evidence from Brazil (and Other BRIK Countries). Journal of Corporate Finance, 18(4), 934-952. http://dx.doi.org/10.1016/j.jcorpfin.2011.10.001

Borisova, G., Brockman, P., Salas, J. M., \& Zagorchev, A. (2012). Governement Ownership and Corporate Governance: Evidence from the EU. Journal of Banking \& Finance, 36, 2917-2934. http://dx.doi.org/10.1016/j.jbankfin.2012.01.008

Boubaker, S., Hatem, M., \& Rjiba, H. (2014). Large Controlling Shareholders and Stock Price Synchronicity. Journal of Banking \& Finance, 40, 80-96. http://dx.doi.org/10.1016/j.jbankfin.2013.11.022 
Boubakri, N., Cosset, J., \& Guedhami, O. (2005, May). Postprivatization Corporate Governance: The Role of Ownership Structure and Investor Protection. Journal of Financial Economics, 76(2), pp.369-399. http://dx.doi.org/10.1016/j.jfineco.2004.05.003

Brockman, P., \& Chung, D. Y. (2003, April). Investor Protection and Firm Liquidity. Journal of Finance, 58(2), 921-937. http://dx.doi.org/10.1111/1540-6261.00551

Burkart, M., Panunzi, F., \& Shleifer, A. (2003, October). Family Firms. Journal of Finance, 8(5), $2167-2201$. http://dx.doi.org/10.1111/1540-6261.00601

Campbell, J., Y., Lettau, M., Malkiel, B. G., \& Xu, Y. (2001, February). Have Individual Stocks Become More Volatile? An Empirical Exploration of Idiosyncratic Risk. Journal of Finance, 56(1), 1-43. http://dx.doi.org/10.1111/0022-1082.00318

Chan, K., \& Hameed, A. (2006, April). Stock Price Synchronicity and Analyst Coverage in Emerging Markets. Journal of Financial Economics, 80(1), 115-147. http://dx.doi.org/10.1016/j.jfineco.2005.03.010

Chernykh, L. (2008, April). Ultimate Ownership and Control in Russia. Journal of Financial Economics, 88(1), 169-192. http://dx.doi.org/10.1016/j.jfineco.2007.05.005

Claessens, S., Djankov, S., \& Lang, L. H. P. (2000). The Separation of Ownership and Control in East Asian Corporations. Journal of Financial $\quad$ Economics, $\quad 58(1 \& 2), \quad 81-112$. http://dx.doi.org/10.1016/S0304-405X(00)00067-2

Claessens, S., \& Yurtoglu, B. B. (2013). Corporate Governance in Emerging Markets: A Survey. Emerging Markets Review, 15, 1-33. http://dx.doi.org/10.1016/j.ememar.2012.03.002

Cumming, D., Johan, S., \& Li, D. (2011, March). Exchange trading Rules and Stock Market Liquidity. Journal of Financial Economics, 99(3), 651-671. http://dx.doi.org/10.1016/j.jfineco.2010.10.001

Durnev, A., Morck, R., \& Yeung, B. (2004, February). Value-Enhancing Capital Budgeting and Firm-specific Stock Return Variation. Journal of Finance, 59(1), 65-105. http://dx.doi.org/10.1111/j.1540-6261.2004.00627.x

Durnev, A., Morck, R., Yeung, B., \& Zarowin, P. (2003, December). Does Greater Firm-Specific Return Variation Mean More or Less Informed Stock Pricing?. Journal of Accounting Research, 41(5), 797-836. http://dx.doi.org/10.1046/j.1475-679x.2003.00124.x

Faccio, M., \& Lang, L. H. P. (2002, September). The Ultimate Ownership of Western European Corporations. Journal of Financial Economics, 65(3), 325-396. http://dx.doi.org/10.1016/s0304-405x(02)00146-0

Foley, F., \& Greenwood, R. (2010, September). The Evolution of Corporate Ownership After IPO: The Impact of Investor Protection. Review of Financial studies, 23(3), 1231-1260. http://dx.doi.org/10.1093/rfs/hhp069

Fracassi, C., \& Tate, G. (2012, February). External Networking and Internal Firm Governance. Journal of Finance, 67(1), 153-194. http://dx.doi.org/10.1111/j.1540-6261.2011.01706.x

Giannetti, M., \& Koskinen, Y. (2010, February). Investor Protection, Equity Returns, and Financial Globalization. Journal of Financial and Quantitative Analysis, 45(1), 135-168. http://dx.doi.org/10.1017/S0022109009990524

Gul, F. A., Kim, J., \& Qiu, A. A. (2010, March). Ownership Concentration, Foreign Shareholding, Audit Quality, and Stock Price Synchronicity: Evidence from China. Journal of Financial Economics, 95(3), 425-442. http://dx.doi.org/10.1016/j.jfineco.2009.11.005

Hong, H., Torous, W., \& Valkanov, R. (2007, February). Do Industries Lead Stock Markets?. Journal of Financial Economics, 83(2), 367-396. http://dx.doi.org/10.1016/j.jfineco.2005.09.010

Jiang, L., Kim, J., \& Pang, L. (2013, September). Insiders Incentives for Asymmetric Disclosure and Firm-Specific Information Flows. Journal of Banking \& Finance, $37(9)$, 3562-3576. http://dx.doi.org/10.1016/j.jbankfin.2013.05.001

Jin, L., \& Myers, S. C. (2006, February). $R^{2}$ Around the World: New Theory and New Test. Journal of Financial Economics, 79(2), 257-292. http://dx.doi.org/10.1016/j.jfineco.2004.11.003

John, K., Litov, L., \& Yeung, B. (2008, August). Corporate Governance and Risk-Taking. Journal of Finance, 63(1), 1679-1728. http://dx.doi.org/10.1111/j.1540-6261.2008.01372.x

Kalpper, L. F., \& Love, I. (2004, November). Corporate Governance, Investor Protection, and Performance in Emerging markets. Journal of Corporate Finance, $10(5), \quad 703-728$. http://dx.doi.org/10.1016/S0929-1199(03)00046-4 
La Porta, R., Lopez-De-Silanes, F., \& Shleifer, A. (1999, April). Corporate Ownership around the World. Journal of Finance, 54(2), 471-517. http://dx.doi.org/10.1111/0022-1082.00115

La Porta, R., Lopez-De-Silanes, F., \& Shleifer, A. (2002, February). Government Ownership of Banks. Journal of Finance, 57(1), 265-301. http://dx.doi.org/10.1111/1540-6261.00422

La Porta, R., Lopez-De-Silanes, F., \& Shleifer, A. (2006, February). What Works in Securities Laws. Journal of Finance, 61(1), 1-32. http://dx.doi.org/10.1111/j.1540-6261.2006.00828.x

La Porta, R., Lopez-De-Silanes, F., Shleifer, A., \& Vishny, R. (2000). Investor Protection and Corporate Governance. Journal of Financial Economics, 58(1\&2), 3-27. http://dx.doi.org/10.1016/S0304-405X(00)00065-9

La Porta, R., Lopez-De-Silanes, F., Shleifer, A., \& Vishny, R. W. (1997, July). Legal Determinants of External Finance. Journal of Finance, 5(3), 1131-1150. http://dx.doi.org/10.1111/j.1540-6261.1997.tb02727.x

La Porta, R., Lopez-De-Silanes, F., Shleifer, A., \& Vishny, R. W. (1998, December). Law and Finance. Journal of Political Economy, 106(6), 1113-1151. http://dx.doi.org/10.1086/250042

Lagoarde-Segot, T. (2009, October). Financial Reforms and Time-varying Microstructure in Emerging Equity Markets. Journal of Banking \& Finance, 33(10), 1755-1769. http://dx.doi.org/10.1016/j.jbankfin.2009.01.007

Li, D., Nguyen, Q. N., Pham, P. K., \& Wei, S. X. (2011, August). Large Foreign Ownership and Firm-Level Stock Return Volatility in Emerging Markets. Journal of Financial \& Quantitative Analysis, 46(4), 1127-1155. http://dx.doi.org/10.1017/S0022109011000202

Lo, A. W., \& Mackinaly, A. C. (1990). When Are Contrarian Profits Due to Stock Market Overreaction?. Review of Financial Studies, 3(2), 175-205. http://dx.doi.org/10.1093/rfs/3.2.175

Mclean, R. D., Zhang, T., \& Zhao, M. (2012, February). Why Does the Law Matter? Investor Protection and its Effects on Investment, Finance, and Growth. Journal of Finance, 67(1), 313-350. http://dx.doi.org/10.1111/j.1540-6261.2011.01713.x

Morck, R., Yeung, B., \& Yu, W. (2000). The Information Content of Stock Markets: Why Do Emerging Markets have Synchronous Stock Price Movements?. Journal of Financial Economics, 58(1\&2), 215-260. http://dx.doi.org/10.1016/S0304-405X(00)00071-4

Piotroski, J. D., \& Roulstone, D. T. (2004, October). The Influence of Analysts, Institutional Investors, and Insiders on the Incorporation Market, Industry, and Firm-Specific Information into Stock Prices. The Accounting Review, 79(4), 1119-1151. http://dx.doi.org/10.2308/accr.2004.79.4.1119

Roll, R. (1988, July). $R^{2}$. Journal of Finance, 43(2), 541-566. http://dx.doi.org/10.1111/j.1540-6261.1988.tb04591.x

Wrugler, J. (2000). Financial Markets and the Allocation of Capital. Journal of Financial Economics, 58(1\&2), 187-214. http://dx.doi.org/10.1016/S0304-405X(00)00070-2

\section{Notes}

Note 1. Foley and greenwood (2010) show that in countries with strong investor protection, ownership concentration decreases as the firm grows.

Note 2. Kalpper and Love, (2004) show that firm-level governance matters more in weak legal environments. Black et al. (2012) propose a flexible approach to governance as country and firm-specific governance indicators can predict market value for nonmanufacturing, small, and high-growth firms.

Note 3. According to the World Bank records, the MENA region includes the countries: Jordan, Syria, Lebanon, Morocco, Egypt, West Bank and Gaza, Iraq, Iran, Israel, Arab Gulf countries, Tunisia, Algeria, Yemen, Djibouti, and Libya.

Note 4. See La Porta et al. (1998) and La Porta et al. (2006) for empirical investigation of the quality of investor protection laws and their enforcement in many developed and developing countries of which Jordan is one.

Note 5. Cumming et al. (2011) show that Jordanian equity market enables market and price manipulation as it scored low on both indices.

Note 6. Lagoarde-Segot (2009), finds that Jordanian equity market is the second least volatile among emerging markets.

Note 7. This observation is consistent with the theoretical predictions of Burkart et al. 2003 that when legal protection of shareholders is poor, there is no separation of ownership and management. 